Efek Pandemi Covid-19 Terhadap Kecemasan Ibu Selama Kehamilan

\title{
Systematic Review: The Covid-19 Pandemic Effects on Maternal Anxiety During Pregnancy
}

\author{
Niken Bayu Argaheni* \\ *) Jurusan Kebidanan, FK, Universitas Sebelas Maret, Jl. Ir. Sutami 36 A, Kentingan Surakarta 57126 telp. \\ (0271) 662622
}

Korespondensi: nikenbayuargaheni@staff.uns.ac.id

\begin{abstract}
ABSTRAK
Latar Belakang: Kecemasan adalah respons umum terhadap situasi stres apa pun. Wanita hamil lebih mungkin terkena penyakit virus, dan Coronavirus dapat menyebabkan stres dan kecemasan pada wanita hamil di berbagai belahan dunia. Penelitian ini bertujuan untuk mengetahui pengaruh pandemi Covid-19 terhadap kecemasan ibu hamil.

Metode: Tinjauan sistematis menggunakan database: Google Cendekia. Hasil pencarian yang memenuhi kriteria kemudian dianalisis.

Hasil: Banyaknya berita media massa dan media sosial dengan pemberitaan terkait COVID19 dan penyebaran informasi di dalamnya memberikan iklim ketakutan, ketidakpastian dan kecemasan, tentang masa kini dan masa depan. Umumnya wanita hamil mengalami perasaan tidak pasti dan cemas terkait persalinan, persalinan, kehadiran bayi, dan perawatan bayi yang baru lahir.

Kesimpulan: Ibu hamil memiliki dampak psikologis yang lebih besar serta kecemasan yang lebih tinggi selama pandemi COVID-19. Identifikasi ibu hamil yang berisiko tinggi mengalami kecemasan yang terjadi selama pandemi Covid-19 penting dilakukan agar petugas kesehatan dapat menyarankan intervensi psikologis dini dan mencegah beberapa komplikasi terkait stres dalam kehamilan.
\end{abstract}

Kata kunci: ibu hamil, kecemasan, pandemi Covid-19

\begin{abstract}
Background: Anxiety is a common response to any stressful situation. Pregnant women are more likely to catch viral illnesses, and the Coronavirus can cause stress and anxiety in pregnant women in different parts of the world. The purpose of this study was to determine the effect of the Covid-19 pandemic on maternal anxiety during pregnancy.

Method: Systematic review using the database: Google Scholar. The search results that meet the criteria are then analyzed for articles.

Result: The saturation of mass media and social media with news related to COVID-19 and the dissemination of information in it provides a climate of fear, uncertainty and anxiety, about the present and the future. This will be magnified for pregnant women today who, even without a pandemic, generally pregnant women experience feelings of uncertainty and
\end{abstract}


anxiety related to childbirth, childbirth, the presence of a baby and the care of a newborn. Conclusion: Pregnant women have a greater psychological impact as well as higher anxiety during the COVID-19 pandemic. Identification of pregnant women who are at high risk of anxiety that occurs during the Covid-19 pandemic is important so that health workers can suggest early psychological intervention and prevent some complications related to stress in pregnancy.

Keywords: Pregnant women, anxiety, Covid-19 pandemic

\section{PENDAHULUAN}

Infeksi coronavirus 2019-nCoV (COVID-19) menjadi perhatian internasional di mana Coronavirus telah diidentifikasi sebagai penyebab wabah penyakit pernapasan. Virus ini pertama kali terdeteksi di Wuhan, Cina ${ }^{1}$. SARSCoV-2 (Covid-19) telah menghasilkan dampak yang signifikan secara psikologis terhadap kesehatan mental masyarakat umum, dengan depresi dan kecemasan yang meluas pada fase awal penyakit ${ }^{2-4}$. Informasi yang akurat dari sumber yang dapat dipercaya sangat penting dalam perpindahan secara cepat informasi pada krisis kesehatan global seperti Covid-19, dengan informasi yang salah yang menambah ketakutan dan kecemasan. Kecemasan kesehatan juga berpengaruh pada faktor dalam keberhasilan strategi kesehatan masyarakat untuk mengelola pandemi ${ }^{5,6}$.

Pandemi merupakan tantangan bagi

ketahanan psikologis dan dapat meningkatkan stres ${ }^{6}$. Kecemasan adalah respon umum untuk setiap situasi stres. Wanita hamil lebih mungkin terkena penyakit virus, dan Coronavirus dapat menyebabkan stres dan kecemasan pada wanita hamil di berbagai belahan dunia ${ }^{6,7}$. Wanita hamil, sebagai populasi yang rentan dan membutuhkan perhatian khusus, dalam hal ini berikut kecemasan yang menyertainya ${ }^{8}$. Kehamilan pada wanita, serta perubahan mental dan fisik selama kehamilan, menyebabkan wanita lebih mungkin berisiko untuk mengalami stress ${ }^{9}$. Prevalensi gangguan kecemasan selama kehamilan, dalam negara maju dan negara berkembang, masing-masing 10 dan $25 \%^{10,11}$. Gejala kecemasan selama kehamilan muncul sebagai faktor risiko independen untuk kebidanan yang dikaitkan dengan outcome maupun hasil dari perkembangan yang merugikan ${ }^{12}$. Kecemasan antenatal dapat menjadi faktor risiko masalah kesehatan mental ibu, seperti meningkatkan kemungkinan depresi pascanatal ${ }^{13}$, gangguan ikatan ibu dan bayi ${ }^{14}$, komplikasi obstetri seperti lama persalinan, persalinan prematur ${ }^{15}$ dan gangguan pertumbuhan janin ${ }^{16,17}$.

Berbagai penelitian telah menunjukkan bahwa semakin besar kecemasan selama kehamilan, semakin besar kemungkinannya operasi caesar akan dipilih sebagai metode persalinan, dengan asumsi memiliki komplikasi yang lebih besar pada ibu dan janin. Peningkatan insiden seksio sesarea biasanya diikuti lebih banyak komplikasi maternal dan neonatal yang tidak sesuai, yang membutuhkan lebih banyak perawatan postpartum dan meningkatkan beban keuangan untuk sistem kesehatan. Mengingat kondisi stres karena epidemi dan kemungkinan kecemasan kesehatan dan tekanan prenatal dalam situasi ini, sebagian besar wanita hamil mungkin memutuskan untuk memilih operasi caesar dengan asumsi bahwa operasi caesar menurunkan kemungkinan kontak ibu hamil dan bayinya dengan virus Covid-19. 18,19 .

\section{METODE PENELITIAN \\ Kriteria Inklusi dan Kriteria Eksklusi \\ Kriteria inklusi artikel yang digunakan: 1) Artikel yang memaparkan tentang Efek Pandemi Covid-19 Terhadap}


Kecemasan Ibu Selama Kehamilan. 2) Artikel yang diterbitkan memiliki bagian yang lengkap. 3) Diterbitkan saat tahun 2020. Kriteria eksklusi artikel meliputi: susunan artikel tidak lengkap.

\section{Alur Pencarian}

Pencarian dilakukan dengan menggunakan database Google Cendekia menggunakan kata kunci: "anxiety, pregnancy, Covid-19". Artikel yang muncul kemudian dipilah sehingga tidak ditemukan artikel dengan judul yang sama. Selanjutnya artikel disortir berdasarkan kriteria inklusi dan eksklusi yang telah ditentukan. Artikel yang mencantumkan abstrak saja akan dieliminasi. Sehingga diperoleh artikel yang akan dianalisis.

\section{Ekstraksi artikel}

Artikel yang sudah didapat kemudian dilakukan ekstraksi. Ekstraksi artikel berdasarkan penulis artikel, tahun terbit artikel, jumlah sampel yang digunakan, alat ukur yang digunakan, hasil penelitian yang dilakukan, dan database artikel.

\begin{tabular}{l}
\hline Hasil pencarian \\
menggunakan kata kunci "anxiety, \\
pregnancy, Covid-19" menggunakan \\
elektronik database Google Cendekia. \\
Hasil pencarian dengan menggunakan tiga \\
kata kunci tersebut menghasilkan 3290 \\
artikel. Kemudian dilakukan penyaringan \\
artikel dengan kriterian inklusi dan \\
eksklusi diperoleh 46 artikel. Pemilihan \\
artikel selanjutnya dengan mengeliminasi \\
duplikasi artikel dengan hasil 21 artikel. \\
Selanjutnya dilakukan eliminasi artikel \\
berdasarkan susunan yang lengkap yaitu \\
sebanyak 17 artikel.
\end{tabular}

Tabel 1. Ekstraksi Artikel

\begin{tabular}{|c|c|c|c|}
\hline Penulis & Tahun & $\mathrm{N}$ & Hasil \\
\hline $\begin{array}{l}\text { Ilenia Mappa, } \\
\text { Flavia } \\
\text { Adalgisa } \\
\text { Distefano and } \\
\text { Giuseppe } \\
\text { Rizzo }\end{array}$ & 2020 & $\begin{array}{l}200 \\
\text { responden } \\
\text { ibu hamil }\end{array}$ & $\begin{array}{l}\text { Kuesioner diisi oleh } 178 \text { wanita }(89 \%) \text {. Ketakutan } \\
\text { tentang COVID-19 yang dapat menyebabkan struktur } \\
\text { janin anomali ditemukan pada } 47 \% \text { responden, } \\
\text { hambatan pertumbuhan janin pada } 65 \% \text { dan kelahiran } \\
\text { prematur pada } 51 \% \text { ibu hamil. Median nilai STAI-T } \\
\text { adalah } 37 \text { dan } 38,2 \% \text { dari kelompok studi. Skor STAI- } \\
\mathrm{T} \geq 40 \text { dibuktikan. Nilai STAI-S secara signifikan lebih } \\
\text { tinggi dengan peningkatan nilai median } 12 \text { poin } \\
\text { (p } \leq 0.0001) \text {. Ada korelasi linier positif antara STAI-T } \\
\text { dan STAI-S (Pearson }=0,59 ; \text { p } \leq 0,0001) \text {. Status } \\
\text { pendidikan yang lebih tinggi dikaitkan dengan } \\
\text { peningkatan prevalensi STAI-S } \geq 40(p=0,004) \text {. }\end{array}$ \\
\hline $\begin{array}{l}\text { X Liu, M } \\
\text { Chen, Y } \\
\text { Wang, L Sun, } \\
\text { J Zhang, Y } \\
\text { Shi, J Wang, } \\
\text { H Zhang, G } \\
\text { Sun, } \\
\text { PN Baker, X } \\
\text { Luo, H Qia, }\end{array}$ & 2020 & $\begin{array}{l}1947 \\
\text { responden } \\
\text { ibu hamil }\end{array}$ & $\begin{array}{l}\text { Penelitian dilakukan di Wuhan dan Chongqing untuk } \\
\text { melihat status kecemasan dan factor yang } \\
\text { mempengaruhinya. Perbedaan diamati pada beberapa } \\
\text { kota dengan karakteristik latar belakang dan sikap } \\
\text { wanita terhadap COVID-19 di Wuhan yang hasilnya } \\
\text { lebih ekstrem. Lebih banyak wanita di Wuhan yang } \\
\text { merasa cemas (24,5 versus } 10,4 \%) \text {. Faktor yang } \\
\text { mempengaruhi kecemasan yang terjadi juga disebabkan } \\
\text { oleh pendapatan rumah tangga, gejala subjektif dan } \\
\text { sikap bu hamil. Secara keseluruhan, keputusan } \\
\text { kebidanan juga mengungkapkan perbedaan yang terjadi } \\
\text { berdasarkan persebaran kota; hal ini terutama } \\
\text { dikarenakan menyangkut preferensi rumah sakit, waktu }\end{array}$ \\
\hline
\end{tabular}




\begin{tabular}{|c|c|c|c|}
\hline Penulis & Tahun & $\mathrm{N}$ & Hasil \\
\hline $\begin{array}{l}\text { Miguel Parra- } \\
\text { Saavedra, Isis } \\
\text { Villa-Villa, } \\
\text { José Pérez- } \\
\text { Olivo, Leidy } \\
\text { Guzman- } \\
\text { Polania, Pablo } \\
\text { Galvis- } \\
\text { Centurion, } \\
\text { Álvaro } \\
\text { Cumplido- } \\
\text { Romero, } \\
\text { Dario } \\
\text { Santacruz- } \\
\text { Vargas, Eliana } \\
\text { Rivera- } \\
\text { Moreno, } \\
\text { Saulo Molina- } \\
\text { Giraldo, } \\
\text { Hernán } \\
\text { Guillen- } \\
\text { Burgos, Edgar } \\
\text { Navarro, } \\
\text { Karen Flórez- } \\
\text { Lozano, } \\
\text { Amanda } \\
\text { Barrero- } \\
\text { Ortega, } \\
\text { Magdalena } \\
\text { Sanz-Cortes, } \\
\text { Jezid Miranda } \\
\end{array}$ & 2020 & $\begin{array}{l}1021 \\
\text { pasien } \\
\text { termasuk } \\
\text { ibu hamil } \\
\text { di } 7 \text { kota } \\
\text { di } \\
\text { Columbia }\end{array}$ & $\begin{array}{l}\text { perawatan atau persalinan prenatal, cara persalinan dan } \\
\text { pemberian makanan bayi. } \\
\text { Sekitar } 1500 \text { wanita hamil mendatangi klinik rumah } \\
\text { sakit antenatal selama penelitian Teknik kuota sampling } \\
\text { digunakan dan sekitar } 50 \text { wanita direkrut dari setiap } \\
\text { klinik. Para ibu hamil diberi nomor dan } 25 \text { peserta } \\
\text { pertama yang memenuhi syarat setiap hari diundang } \\
\text { untuk ambil bagian dalam studi. Usia rata-rata adalah } \\
29,2 \text { (SD } \pm 5,7) \text { tahun dan median (IQR) paritas } 2(1-3) \text {. } \\
\text { Usia kehamilan responden penelitian adalah } 23,3 \text { (SD } \pm \\
10,2) \text { minggu. Dari } 257 \text { pasien yang diteliti, } 191 \\
\text { ( } 74,3 \% \text { mengalami kehamilan tanpa komplikasi pada } \\
\text { saat survei. Secara keseluruhan, prevalensi kecemasan } \\
\text { dan depresi masing-masing adalah } 17,5 \% \text { ( } 45 / 257) \text { dan } \\
19,5 \% \text { (50/257). Dari hasil penelitian, } 73 \text { (28,4\%) } \\
\text { merasa cemas, depresi, atau keduanya. Kelompok usia } \\
\text { termuda } \\
\text { (18-25 tahun) ditemukan memiliki risiko lebih tinggi } \\
\text { (45,5\%) menjadi cemas dan murung. } \\
\text { Sebanyak } 1.021 \text { pasien diundang untuk berpartisipasi, } \\
\text { dan memperoleh } 946 \text { survei yang valid analisisnya. } \\
\text { Tingkat konsekuensi psikologis dari pandemi jauh lebih } \\
\text { besar daripada jumlah pasien yang secara klinis terkena } \\
\text { virus, dengan 50,4\% dari seluruh kohort menunjukkan } \\
\text { gejala kecemasan, } 49,1 \% \text { insomnia, dan } 25 \% \\
\text { menunjukkan gejala depresi. Wanita yang mendapat } \\
\text { informasi lebih cenderung lebih muda, berafiliasi } \\
\text { dengan penerima bantuan bersubsidi, dan dengan } \\
\text { tingkat pendidikan yang lebih rendah. Pengetahuan ibu } \\
\text { hamil tentang infeksi SARS-CoV-2 masih jauh dari } \\
\text { realitas dan ini tampaknya terkait dengan efek tidak } \\
\text { langsung pada perhatian dan stres psikologis wanita } \\
\text { hamil di Kolombia. }\end{array}$ \\
\hline
\end{tabular}




\begin{tabular}{|c|c|c|c|}
\hline Penulis & Tahun & $\mathrm{N}$ & Hasil \\
\hline $\begin{array}{l}\text { Heidi Preis, } \\
\text { Brittain } \\
\text { Mahaffey, } \\
\text { Cassandra } \\
\text { Heiselman, } \\
\text { Marci Lobel }\end{array}$ & 2020 & $\begin{array}{l}788 \\
\text { responden } \\
\text { ibu hamil }\end{array}$ & $\begin{array}{l}\text { Peserta rata-rata berusia } 29,19 \pm 5,29 \text { tahun dan usia } \\
\text { kehamilan rata-rata adalah } 25,3 \pm 9,1 \text { minggu. Sekitar } \\
\text { tiga perempat berkulit putih dan non-Hispanik }(\mathrm{n}=608 \text {, } \\
77,2 \%) \text {; hampir setengahnya adalah primipara }(\mathrm{n}=362 \text {, } \\
45,9 \%) .166 \text { wanita }(21,1 \%) \text { menunjukkan tidak ada } \\
\text { gejala kecemasan minimal (GAD-7 }=0-4), 280(35,6 \%) \\
\text { menunjukkan gejala kecemasan ringan }(\mathrm{GAD}-7=5-9) \text {, } \\
170(21,6 \%) \text { menunjukkan gejala kecemasan sedang } \\
(\mathrm{GAD}-7=10-14) \text {, dan } 171(21,7 \%) \text { menunjukkan gejala } \\
\text { kecemasan yang parah }(\mathrm{GAD}-7 \geq 15) \text {. }\end{array}$ \\
\hline $\begin{array}{l}\text { Claudia } \\
\text { Ravaldia, } \\
\text { Alyce } \\
\text { Wilsond, } \\
\text { Valdo Riccac, } \\
\text { Caroline } \\
\text { Homerd, } \\
\text { Alfredo } \\
\text { Vannaccia }\end{array}$ & 2020 & $\begin{array}{l}200 \\
\text { responden } \\
\text { ibu hamil }\end{array}$ & $\begin{array}{l}\text { Tujuh puluh dua wanita ( } 36,0 \% \text { responden) mengalami } \\
\text { a } \\
\text { tekanan psikologis sebelumnya khususnya, sebagian } \\
\text { besar gangguan yang dilaporkan adalah kecemasan }(62 \text {, } \\
31.0 \%) \text {, gangguan mood }(22 ; 11,0 \%) \text {, gangguan makan } \\
(8 ; 4,0 \%) \text { atau gangguan obsesif-kompulsif }(2 ; 1,0 \%) \text {. } \\
100 \text { wanita dilaporkan memiliki menderita satu atau } \\
\text { lebih kerugian sebelumnya, termasuk keguguran }(110 \text {, } \\
55.0 \%) \text { atau kehilangan perinatal (36 wanita, 18.0\%); } \\
\text { wanita bisa } \\
\text { untuk memilih banyak tanggapan. Distribusi psikologi } \\
\text { distress sebelumnya tidak berbeda secara signifikan } \\
\text { antara wanita dengan atau tanpa kerugian sebelumnya. }\end{array}$ \\
\hline $\begin{array}{l}\text { Orit } \\
\text { Taubman-- } \\
\text { Ben-Ari, } \\
\text { Miriam } \\
\text { Chasson, } \\
\text { Salam Abu } \\
\text { Sharkia and } \\
\text { Efrat Weiss }\end{array}$ & 2020 & $\begin{array}{l}336 \\
\text { responden } \\
\text { ibu hamil }\end{array}$ & $\begin{array}{l}\text { Tingkat kecemasan terkait COVID-19 cukup tinggi } \\
\text { (banyak atau sangat), dengan yang tertinggi mengenai } \\
\text { keamanan di tempat umum dan transportasi }(87,5 \% \text {, } \\
70 \% \text {, masing-masing), diikuti oleh kekhawatiran atas } \\
\text { kemungkinan infeksi anggota keluarga lain dan } \\
\text { Kesehatan janin }(71,7 \%, 70 \% \text {, masing-masing), pergi } \\
\text { untuk pemeriksaan kehamilan }(68,7 \%, \text {, tertular sendiri, } \\
\text { dan persalinan }(59,2 \%, 55,4 \% \text {, masing-masing). } \\
\text { Meskipun ada kekhawatiran terkait COVID-19 wanita } \\
\text { hamil yang ditandai dengan beragam sosiodemografi } \\
\text { variabel, dengan nuansa yang sangat kecil, wanita Arab } \\
\text { lebih banyak cemas tentang setiap masalah daripada } \\
\text { wanita Yahudi. }\end{array}$ \\
\hline $\begin{array}{l}\text { Miriam } \\
\text { Chasson, Orit } \\
\text { Taubman - } \\
\text { Ben-Ari and } \\
\text { Salam Abu- } \\
\text { Sharkia }\end{array}$ & 2020 & $\begin{array}{l}403 \\
\text { responden } \\
\text { ibu hamil }\end{array}$ & $\begin{array}{l}\text { Wanita Arab secara signifikan lebih tinggi mengalami } \\
\text { kecemasan terkait infeksi dan tekanan psikologis } \\
\text { daripada orang Yahudi. Selain itu, wanita Yahudi } \\
\text { dilaporkan jauh lebih tinggi untuk memiliki penguasaan } \\
\text { diri dibandingkan wanita hamil Arab. Akhirnya, } \\
\text { kesehatan yang lebih buruk, Ketika menjadi seorang } \\
\text { wanita Arab, dan tingkat penguasaan diri yang lebih } \\
\text { rendah, ketahanan, dan dukungan sosial yang dirasakan, } \\
\text { serta kecemasan terkait infeksi, berkontribusi secara } \\
\text { signifikan lebih besar pada tekanan psikologis. }\end{array}$ \\
\hline
\end{tabular}




\begin{tabular}{|c|c|c|c|}
\hline Penulis & Tahun & $\mathrm{N}$ & Hasil \\
\hline $\begin{array}{l}\text { Chongyu Yue, } \\
\text { Cuiping Liu, } \\
\text { Jing Wang, } \\
\text { Meng Zhang, } \\
\text { Hongjing Wu, } \\
\text { Chunrong Li } \\
\text { and Xiuling } \\
\text { Yang }\end{array}$ & 2020 & $\begin{array}{l}308 \\
\text { responden } \\
\text { ibu hamil }\end{array}$ & $\begin{array}{l}\text { Penelitian ini memiliki } 308 \text { partisipan dengan rata-rata } \\
31,02 \pm 3,91 \text { tahun. Selama periode pencegahan dan } \\
\text { pengendalian epidemi, sebagian besar wanita hamil } \\
\text { mengadopsi tindakan perlindungan, seperti memakai } \\
\text { masker }(97,4 \%) \text {, Sering mencuci tangan }(88,3 \%) \text { dan } \\
\text { tinggal di rumah }(76,3 \%) \text {. Rata-rata skor SAS, SSRS } \\
\text { dan persepsi risiko dari peserta adalah } 42.45 \pm 6.98 \text {, } \\
44.60 \pm 7.00 \text { dan } 21.60 \pm 5.74 \text {, masing-masing. Efek } \\
\text { total dari dukungan sosial ibu pada kecemasan adalah } \\
-2.63 \text { (interval kepercayaan } 95 \%(\mathrm{CI}):-4.40 \sim-1.44 \text {, p } \\
<.001) \text {, efek langsungnya adalah }-1.44(95 \% \mathrm{CI}:-2.74 \\
\sim-0.35, \mathrm{p}<.05) \text { dan efek tidak langsungnya adalah } \\
-1.19(95 \% \mathrm{CI}:-2.49 \sim-0.51, \mathrm{p}<.001) .\end{array}$ \\
\hline $\begin{array}{l}\text { Najmeh } \\
\text { Maharlouei, } \\
\text { Pedram } \\
\text { Keshavarz, } \\
\text { Kamran B. } \\
\text { Lankarani }\end{array}$ & 2020 & $\begin{array}{l}540 \\
\text { responden } \\
\text { ibu hamil }\end{array}$ & $\begin{array}{l}540 \text { ibu hamil menjawab kuesioner. } 83,5 \% \text { tidak } \\
\text { memiliki komorbiditas. Skor depresi secara signifikan } \\
\text { lebih tinggi pada ibu hamil yang tidak memiliki asuransi } \\
\text { apapun }(\mathrm{OR}=2,5) \text { dan pada ibu hamil dengan kesehatan } \\
\text { diri yang buruk (SRH) }(\mathrm{OR}=27,8) \text {. Ibu hamil dengan } \\
\text { SRH rendah dan dua atau lebih komorbiditas memiliki } \\
\text { kemungkinan lebih tinggi untuk memiliki subskala } \\
\text { kecemasan tingkatl; } 6,9,3,7 \text { kali, secara retrospektif. }\end{array}$ \\
\hline $\begin{array}{l}\text { Claudia } \\
\text { Ravaldi, } \\
\text { Valdo Ricca, } \\
\text { Alyce Wilson, } \\
\text { Caroline } \\
\text { Homer, } \\
\text { Alfredo } \\
\text { Vannacci }\end{array}$ & 2020 & $\begin{array}{l}1015 \\
\text { responden } \\
\text { ibu hamil }\end{array}$ & $\begin{array}{l}\text { Dari } 1.015 \text { ibu hamil yang dijangkau, } 737(72,6 \%) \\
\text { menjawab kuesioner sepenuhnya; tidak ada wanita yang } \\
\text { melaporkan infeksi COVID-19. Usia rata-rata adalah } \\
34,4 \text { tahun [kuartil } 31,7,37,2] \text {, hari median dalam } \\
\text { lockdown adalah } 13,1[11,0,17,0] \text {, rata-rata minggu } \\
\text { kehamilan adalah } 27,8[19,8,34,0] \text {. Secara klinis gejala } \\
\text { PTSD yang signifikan ditemukan pada } 75 \text { wanita } \\
(10,2 \% \text {, NSESSS cut-off } 24) \text { dan secara klinis gejala } \\
\text { kecemasan yang signifikan ditemukan pada } 160 \text { wanita } \\
(21,7 \% \text {, batas STAI-Y1 50). Wanita tidak terlalu } \\
\text { mengkhawatirkan kesehatan mereka sendiri daripada } \\
\text { kesehatan bayi dan orang tua mereka keluarga. } \\
\text { Kecemasan sebelumnya memprediksi kekhawatiran } \\
\text { yang lebih tinggi dan gejala PTSD; depresi sebelumnya } \\
\text { dan kecemasan secara independen terkait dengan gejala } \\
\text { PTSD saat ini }\end{array}$ \\
\hline $\begin{array}{l}\text { Johnbosco I. } \\
\text { Nwafor, } \\
\text { Ijeoma N. } \\
\text { Okedo-Alex, } \\
\text { Arinze C. } \\
\text { Ikeotuonye }\end{array}$ & 2020 & $\begin{array}{l}456 \\
\text { responden } \\
\text { ibu hamil }\end{array}$ & $\begin{array}{l}\text { Depresi berat dan sangat parah dilaporkan pada } 33 \\
(7,2 \%) \text { dan } 29(6,4 \%) \text { peserta masing-masing. } 15(3,3 \%) \\
\text { dan } 35(7,7 \%) \text { perempuan telah parah dan kecemasan } \\
\text { yang sangat parah masing-masing. 105 (23\%) } \\
\text { mengalami kecemasan parah sedangkan } 76(16,7 \%) \\
\text { melaporkan stres yang sangat parah. Multiparitas }(2-4) \\
\text { dan pekerjaan seperti perdagangan dan pertanian adalah } \\
\text { prediktor depresi sedangkan kakek-nenek, perkotaan } \\
\text { tempat tinggal dan perdagangan diidentifikasi sebagai } \\
\text { prediktor kecemasan dan stres. }\end{array}$ \\
\hline $\begin{array}{l}\text { Tetsufumi } \\
\text { Suda, Yumiko } \\
\text { Miura, } \\
\text { Motoko } \\
\text { Katayama, } \\
\text { Hiroshi }\end{array}$ & 2020 & $\begin{array}{l}142 \\
\text { responden } \\
\text { ibu hamil }\end{array}$ & $\begin{array}{l}\text { Kehadiran depresi, kecemasan, dan stres diidentifikasi } \\
17,7 \%, 12,5 \% \text {, dan } 12,5 \% \text { dari peserta. Sedangkan } \\
\text { kekhawatiran tentang keuangan rumah tangga karena } \\
\text { wabah COVID-19 secara independen berkontribusi } \\
\text { pada dampak psikologis; adanya hidung pelepasan dan }\end{array}$ \\
\hline
\end{tabular}




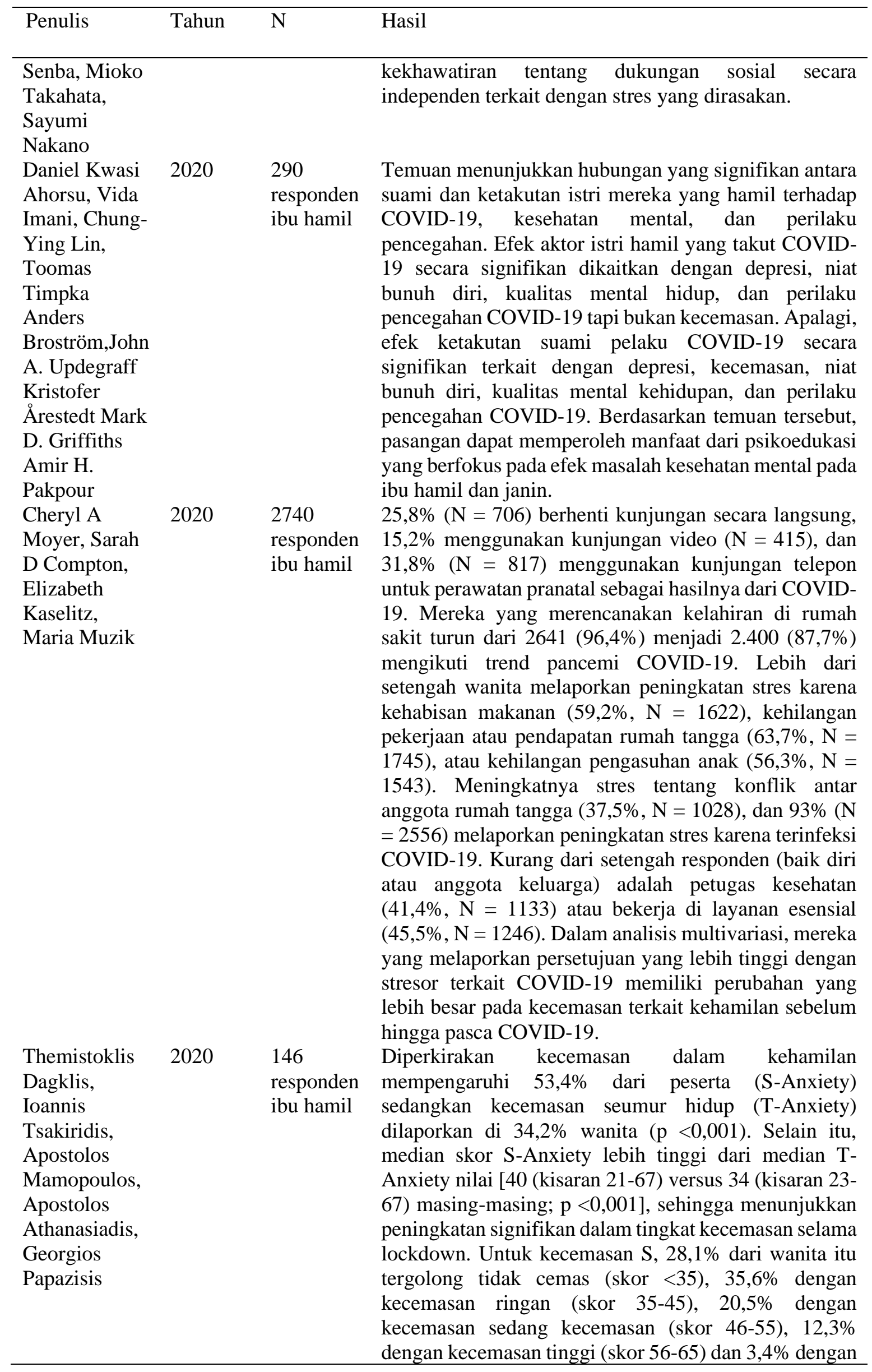




\begin{tabular}{|c|c|c|c|}
\hline Penulis & Tahun & $\mathrm{N}$ & Hasil \\
\hline $\begin{array}{l}\text { Yanting Wu, } \\
\text { Chen Zhang; } \\
\text { Han Liu; } \\
\text { Chenchi } \\
\text { Duan,; Cheng } \\
\text { Li; Jianxia } \\
\text { Fan; Hong Li; } \\
\text { Lei Chen; } \\
\text { Hualin Xu; } \\
\text { Xiangjuan Li; } \\
\text { Yi Guo; } \\
\text { Yeping Wang; } \\
\text { Xiufeng Li, } \\
\text { BA; Jing Li, } \\
\text { BA; } \\
\text { Ting Zhang, } \\
\text { MD; Yiping } \\
\text { You, BA; } \\
\text { Hongmei Li; } \\
\text { Shuangqi } \\
\text { Yang, BA; } \\
\text { Xiaoling Tao, } \\
\text { BA; Yajuan } \\
\text { Xu, BA; } \\
\text { Haihong Lao, } \\
\text { BA; } \\
\text { Ming Wen, } \\
\text { BA; Yan } \\
\text { Zhou, BA; } \\
\text { Junying } \\
\text { Wang, BA; } \\
\text { Yuhua Chen, } \\
\text { BA; Diyun } \\
\text { Meng; Jingli } \\
\text { Zhai; } \\
\text { Youchun Ye, } \\
\text { MD; } \\
\text { Qinwen } \\
\text { Zhong, BA; } \\
\text { Xiuping } \\
\text { Yang, BA; } \\
\text { Dan Zhang; } \\
\text { Jing Zhang, } \\
\text { BA; Xifeng }\end{array}$ & 2020 & $\begin{array}{l}4124 \\
\text { responden } \\
\text { ibu hamil }\end{array}$ & 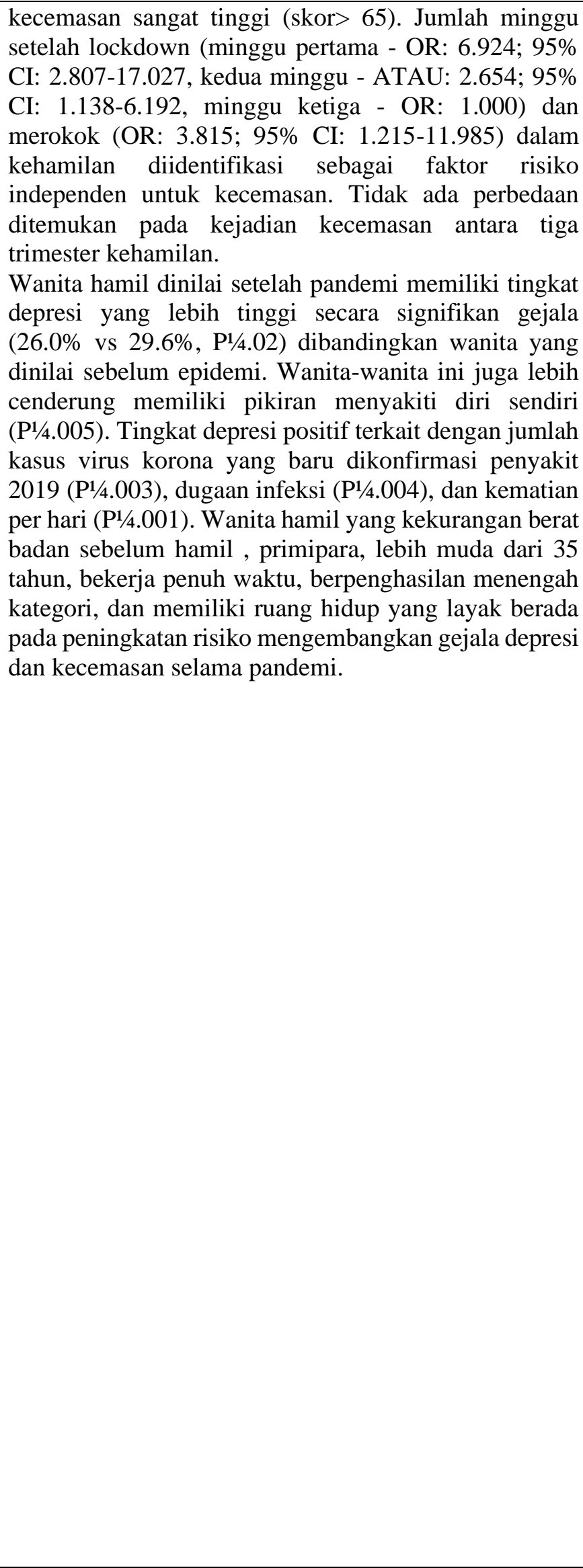 \\
\hline
\end{tabular}




\begin{tabular}{llll}
\hline Penulis & Tahun & $\mathrm{N}$ & Hasil \\
\hline Wu; Wei & & \\
Chen, BA; & & \\
Cindy-Lee & & \\
Dennis; He- & & \\
feng Huang, & & \\
MD & & \\
\hline
\end{tabular}

\section{PEMBAHASAN}

Pandemi Covid-19 telah

menimbulkan kecemasan di kalangan ibu hamil yang populasinya meningkat. ${ }^{3,5,6,20-}$ ${ }^{26}$ Wanita adalah subyek yang paling peduli dengan kerabat yang usianya tua, kemudian anak-anaknya, diikuti oleh janin yang belum lahir. Pasien dalam penelitian ${ }^{5}$ paling tidak peduli tentang kesehatannya sendiri. Dalam penelitian, lebih dari separuh wanita mengalami kecemasan yang signifikan berhubungan dengan kesehatan. Instruksi pemerintah tentang jarak sosial telah menghasilkan hal yang besar pada perubahan perilaku di antara pasien hamil ${ }^{27}$. Wanita hamil berada di bawah tekanan tambahan yang mungkin memiliki efek merugikan secara tidak langsung pada kesehatan fisik dan mentalnya ${ }^{28}$. Sangat penting untuk menyadari hal ini dan mendukung pasien melalui pemberian informasi yang akurat dan terkini, dengan strategi sederhana seperti dalam penelitian ${ }^{5,6}$ yang mengarah pada peningkatan kepuasan dan pemberdayaan pasien. Media buletin dan berita televisi tetap menjadi sumber yang paling banyak digunakan untuk sumber informasi. Beberapa pasien menggunakan twitter atau media sosial lainnya sebagai sumber informasi, yang meningkatkan penyebaran informasi yang salah melalui media sosial. ${ }^{6,29}$

Wanita dengan riwayat tekanan psikologis (sebelumnya kecemasan atau gangguan depresi) menunjukkan perhatian yang lebih besar pada sisi kesehatan dan kesejahteraan pasangannya dibandingkan wanita tanpa sejarah psikologis. Hal ini sekaligus memperkuat peran penting seorang partner selama kehamilan, persalinan dan periode postpartum, terutama bagi wanita dengan riwayat kesehatan mental yang buruk ${ }^{23,30-32}$. Hal ini sangat penting mengingat meningkatnya laporan bahwa wanita menjalani persalinan sendirian di rumah sakit karena rumah sakit menerapkan langkah-langkah pembatasan dan jaga jarak untuk mencegah penularan COVID$19^{3,32}$. Kejenuhan media massa dan media sosial dengan berita terkait COVID-19 dan penyebaran informasi ini di dalamnya memberikan iklim ketakutan, ketidakpastian dan kecemasan, tentang masa kini dan masa depan. Ini akan diperbesar untuk wanita hamil saat ini yang bahkan tanpa adanya pandemi umumnya ibu hamil mengalami perasaan tidak pasti dan kecemasan terkait persalinan, persalinan, kehadiran bayi serta perawatan bayi baru lahir ${ }^{23,33}$.

Penelitian yang dilakukan oleh ${ }^{5}$ menunjukkan bahwa kebanyakan wanita $(83,1 \%$, 59/71) tidak sering mengkhawatirkan kesehatannya sebelumnya. Selama fase pandemi, lebih dari separuh wanita $(50,7 \%, 36 / 71)$ sering mengkhawatirkan kesehatannya sepanjang waktu. Wanita hamil memiliki kecemasan yang meningkat tentang kesehatan kerabatnya yang lebih tua $(83,3 \%, 55 / 66)$. Ini diikuti oleh kekhawatiran tentang anakanaknya yang lain $(66,7 \%, 28 / 42)$ dan kemudian bayi/janinnya yang belum lahir $(63,4 \%, 45 / 71)$. Lebih dari 35\% pasien (25/71) mengisolasi diri untuk menghindari tertular penyakit. Sepertiga $(32,4 \%, 23 / 71)$ mulai tinggal di rumah dan karena ketakutan tentang virus sementara yang lain termasuk masuk lima pasien $(19,7 \%, 14 / 71)$ mulai bekerja dari rumah. Hampir setengah dari wanita yang ditanyai 
$(46,5 \%, 33 / 71)$ mengubah metode/cara untuk naik angkutan. Pembelian massal dilaporkan oleh banyak responden berupa $(66,2 \%$ makanan, $42,3 \%$ pembersih tangan, 25,4\% perlengkapan mandi, 9,9\% bahan bakar, 8,5\% dan alat pelindung diri). Menyusul penutupan sekolah di Irlandia sebelum pengumpulan data, 38,2\% (26/71) wanita membutuhkan tunjangan anak tambahan. Sebanyak 23,9\% (17/71) harus tinggal di rumah untuk merawat anak-anak yang ada, $11,3 \%(8 / 71)$ mengandalkan kakek-nenek dan 5,6\% (4/71) menerima bantuan dari teman untuk mengasuh anaknya. Sumber informasi yang dimanfaatkan oleh pasien termasuk TV Berita $(80,3 \%, 57 / 71)$, situs HSE $(63,4 \%$, 45/71) dan berita nasional aplikasi telepon $(49,3 \%, 35 / 71)$. Proporsi yang lebih kecil menggunakan koran $(25,4 \%, 18 / 71)$, situs web WHO $(16,9 \%, 12 / 71)$, Twitter $(4,2 \%$, $3 / 71)$ atau media sosial lainnya $(11,3 \%$, $8 / 71)^{5}$

Penelitian oleh ${ }^{1}$ menunjukkan bahwa berjangkitnya COVID 19 dan pembatasan gerak menyebabkan peningkatan signifikan kecemasan ibu hamil yang ditunjukkan oleh skor STAI menjadi dua kali lipat saat dibandingkan. Penelitian ini juga menunjukkan peningkatan skor STAI di negara bagian lebih tinggi terkait dengan tingkat kecemasan yang sudah ada sebelumnya yang diukur dengan tingkat STAI. Peningkatan ini juga terkait dengan kecemasan yang dialami oleh ibu hamil dengan status pendidikan maternal yang lebih tinggi, dibandingkan dengan ibu hamil yang berpendidikan lebih rendah. Dalam penelitian, hanya $7 \%$ dari resonden yang menerima informasi dari penyedia layanan kesehata dan pemahamannya tentang COVID-19 diperoleh terutama melalui jurnal, televisi dan konsultasi web. Prevalensi kecemasan yang tinggi berkaitan dengan hasil akhir/outcome perinatal yang abnormal karena lebih dari separuh peserta merasa khawatir bahwa COVID-19 dapat menyebabkan kelainan struktural janin, dan hambatan pertumbuhan atau persalinan prematur meskipun sudah melakukan pemeriksaan USG 2 bulan sebelumnya. ${ }^{1,6,22}$.

Penelitian 34 menunjukkan responden ibu hamil di Wuhan secara signifikan memiliki skor kecemasan yang lebih tinggi. Skor standar rata-rata untuk kecemasan adalah 43,97 (SD 8,71) untuk ibu hamil di Wuhan, dengan seperempat darinya mendapatkan skor 50 atau lebih. Di Chongqing, skor rata-rata 40,37 (SD 7.15) dilaporkan, di antaranya sekitar $90 \%$ mendapat nilai lebih rendah dari 50 . Prevalensi keseluruhan kecemasan selama periode ini adalah $17,2 \%$. Wanita hamil di daerah yang paling parah terkena epidemi (Wuhan) jauh lebih cemas, 18,8 dan 5,7\% yang mengalami kecemasan ringan, dan sedang / berat; dengan proporsi 9,4 dan $1,1 \%$ di Chongqing. Ibu hamil di Sri Lanka pada penelitian ${ }^{35}$ menunjukkan tingkat kecemasan yang lebih tinggi daripada yang diamati di Chongqing, meskipun fakta bahwa Sri Lanka telah berhasil menahan penyebaran virus pada saat penelitian $(10,4 \% \text { vs. } 17,5 \%)^{35}$.

Pada analisis multivariable, menunjukkan pengaruh dari masingmasing faktor latar belakang atau sikap yang dilakukan ibu hamil. Pertama, ibu hamil dari keluarga berpenghasilan menengah setengah lebih mungkin menunjukkan kecemasan daripada yang mendapatkan upah yang sangat tinggi atau rendah. Kedua, wanita di Wuhan sekitar dua kali lebih mungkin untuk mengembangkan kecemasan (rasio odds (OR) 1,83, 95\% CI 1,38-2,41). Ketiga, orang yang demam, batuk, diare atau punya gejala infeksi yang dicurigai lima kali lebih mungkin mengalami kecemasan daripada yang wanita yang sehat (OR 4,92, 95\% CI 1,84-13,17). Selanjutnya sikap terhadap COVID-19 terkait dengan status kecemasan. Wanita hamil dengan pengetahuan relatif lebih banyak tentang COVID-19 dan dengan persepsi risiko yang rasional (tidak terlalu gugup tentang pengendalian epidemi atau pergi keluar), cenderung tidak cemas. Selain itu, ibu 
hamil yang memilih konsultasi medis online menunjukkan sikap positif sebagai fitur perlindungan dari kecemasan (OR $0,65,95 \%$ CI $0,57-0,73)$, sedangkan ibu hamil yang memilih konsultasi psikologis menunjukkan efek sebaliknya (OR 1,31, 95\% CI 1,14-1,52). ${ }^{34}$.

Penelitian ${ }^{34}$ menunjukkan wanita dengan pendapatan menengah pun terlindung dari kecemasan dibandingkan dengan yang memiliki upah tinggi atau upah rendah. Tidak ada karakteristik demografis lain atau faktor-faktor yang berhubungan dengan kehamilan ditemukan pada penelitian terkait kecemasan, meskipun penelitian sebelumnya menunjukkan bahwa usia, pendidikan, pekerjaan, paritas dan usia kehamilan bisa mempengaruhi kecemasan ${ }^{36-38}$. Hidup di pusat epidemi berdampak besar pada tingkat kecemasan. Penelitian ${ }^{34}$ telah mencatat tingginya proporsi wanita yang memperoleh informasi melalui saluran media resmi selama wabah $(84,3 \%)$, meskipun analisis multivariabel tidak menunjukkan hubungan sumber informasi dengan kecemasan. Tingkat kecemasan mungkin diremehkan. Ibu hamil yang tidak terdaftar di rumah sakit dan tidak berpartisipasi pada penelitian dan memiliki sosial ekonomi yang lebih rendah memiliki kemungkinan menderita tingkat kecemasan yang lebih tinggi ${ }^{6,38}$.

$$
\text { Penelitian } 18 \text { menunjukkan }
$$

kecemasan kesehatan wanita menunjukkan perbedaan statistik yang signifikan antara berbagai kelompok $(\mathrm{P}=0,0001)$. Di kelompok pertama, skor tertinggi adalah $35.06 \pm 07.34$ yang diamati pada kelompok yang memilih persalinan pervaginam tetapi ibu hamil memilih operasi caesar selama pandemi Covid-19 ${ }^{18,32}$. Skor terendah dari kecemasan kesehatan skor 27,44 $\pm 4,69$ yang terlihat pada wanita yang cenderung menjalani operasi caesar sebelum epidemi covid-19 tetapi ibu hamil memilih untuk persalinan pervaginam selama epidemi. Pandemi Covid-19 merupakan fenomena langka dalam kehidupan saat ini yang disertai dengan komplikasi jangka panjang dan menimbulkan kekhawatiran bagi pusat kesehatan dan pengobatan masyarakat. Hal ini menyebabkan kekhawatiran terhadap kesehatan yang terkadang berubah menjadi kecemasan dan stres. Dalam beberapa kasus, karena kesulitan dan kecemasan yang parah akibat virus corona, beberapa ibu hamil ingin mengakhiri kehamilan dan menjalani operasi caesar elektif. Dalam berbagai penelitian, peningkatan kecemasan prenatal disertai dengan peningkatan pemilihan seksio sesarea. ${ }^{18}$

Prevalensi Covid-19 merupakan salah satu faktor yang dapat meningkatkan kecemasan dan stres pada ibu hamil. Jarak sosial dan beberapa pembatasan lalu lintas dan karantina adalah di alasan utama yang meningkatkan kecemasan dan stres pada sebagian besar ibu hamil selama penyebaran covid-19. Selain itu, wanita hamil yang membutuhkan lebih banyak dukungan emosional mungkin akan kehilangan dukungan tersebut karena pembatasan yang diterapkan dari pandemi covid-19 karena penurunan hubungan dengan kerabat. Peningkatan tekanan pranatal dan juga aspek kekhawatiran yang lebih tinggi mengenai neonatus daripada aspek lain mengarah pada pemilihan operasi caesar selama terjadinya epidemi covid19. Selain itu, alasan terbanyak memilih sesar selama terjadinya epidemi berdasarkan penjelasan para ibu adalah ketakutan pada status kesehatan janin. Dalam penelitian lain, takut cedera pada janin selama persalinan pervaginam merupakan salah satu faktor yang menentukan dalam memilih operasi caesar 18 .

Penelitian ${ }^{39}$ menunjukkan bahwa dua pertiga dari wanita hamil dalam penelitian ini yang disurvei di Kolombia menunjukkan gejala yang terkait dengan kecemasan serta kekhawatiran tentang penularan vertikal virus dan efeknya pada janin. Gejala yang terkait dengan kecemasan menunjukkan khawatir berlebihan, gugup dan agitasi ${ }^{6}$. Demikian pula, $49 \%$ dari ibu hamil menunjukkan gejala insomnia, dan $25,4 \%$ dari pasien 
menunjukkan gejala depresi ${ }^{39}$. Setelah adanya isolasi, jarak sosial, dan perubahan ekstrim dalam kehidupan sehari-hari, hal itu dapat meningkatkan risiko depresi di kalangan populasi rentan seperti wanita hamil. Oleh karena itu, sangat penting untuk memulai menilai dampak psikologis wabah COVID-19 dalam praktik seharihari. $6,39,40$

Sebelum pandemi, ketakutan akan persalinan dikaitkan kebanyakan wanita dengan konstruksi yang berhubungan dengan nyeri fisik persalinan, dan emosi keika akhirnya bisa bertemu bayi; kegembiraan, kebahagiaan, ketenangan dan rasa tidak sabar yang memungkinkan wanita untuk mempersiapkan momen persalinan dengan sebaik-baiknya dengan segala cara yang mungkin bisa dilakukan. Selama pandemi, perubahan responsnya pun mengejutkan: rasa takut tidak lagi berkorelasi dengan antisipasi, ketidaksabaran, kegembiraan dan perjumpaan, tetapi dengan kesedihan, kesepian, kesedihan, ketidakmampuan, rasa isolasi dan penyempitan. Meskipun begitu, rasa nyeri fisik tetap ada, seperti satu-satunya ciri yang sama dengan konstruksi konsep di masa lalu. Konstruksi terkait dengan ekspektasi positif tersebut terhadap kelahiran termasuk kedekatan dengan pasangan, rasa perlindungan, keamanan dan ketenangan. Selama pandemi, konstruksi ini berubah menjadi perasaan bahaya, kecemasan dan kesepian. Persepsi persalinan berubah, kemungkinan besar dipengaruhi oleh pergeseran sosial dan struktural yang terjadi untuk menahan penyebaran Covid-19 selama pandemi ${ }^{3}$.

\section{KESIMPULAN}

Wanita hamil memiliki dampak psikologis yang lebih besar serta kecemasan yang lebih tinggi pada saat pandemi wabah COVID-19. Identifikasi ibu hamil yang berisiko tinggi terhadap kecemasan yang terjadi pada saat pandemi wabah Covid-19 menjadi penting agar tenaga kesehatan dapat menyarankan intervensi psikologis dini dan pencegahan beberapa komplikasi terkait stres pada kehamilan.

\begin{tabular}{ll}
\hline \multicolumn{1}{c}{ DAFTAR PUSTAKA } \\
\hline Mappa I, Distefano FA, Rizzo G. \\
Effects of coronavirus 19 pandemic \\
on maternal anxiety during \\
pregnancy: a prospectic \\
observational study. J Perinat Med. \\
2020;48(6):545-50.
\end{tabular}

2. Wang C, Pan R, Wan X, Tan Y, Xu L, Ho CS, et al. Immediate Psychological Responses and Associated Factors during the Initial Stage of the 2019 Coronavirus Disease (COVID-19) Epidemic among the General Population in China. QJM. 2020;113(5):311-2.

3. Ravaldi C, Wilson A, Ricca V, Homer C, Vannacci A. Pregnant women voice their concerns and birth expectations during the COVID-19 pandemic in Italy. Women and Birth [Internet]. 2020;(2019). Available from: https://doi.org/10.1016/j.wombi.20 20.07.002

4. Tyrer P, Salkovskis P, Tyrer H, Wang D, Crawford MJ, Dupont S, et al. Cognitive-behaviour therapy for health anxiety in medical patients (Champ): A randomised controlled trial with outcomes to 5 years. Health Technol Assess (Rockv). 2017;21(50):1-88.

5. Corbett GA, Milne SJ, Hehir MP, Lindow SW, O'connell MP. Health anxiety and behavioural changes of pregnant women during the COVID-19 pandemic. Eur J Obstet Gynecol Reprod Biol. 2020;249:96-7.

6. Preis H, Mahaffey B, Heiselman C, Lobel M. Pandemic-related pregnancy stress and anxiety among women pregnant during the 
COVID-19 pandemic. Am J Obstet Gynecol MFM [Internet]. 2020;100155. Available from: https://doi.org/10.1016/j.ajogmf.20 20.100155

7. Schwartz DA, Graham AL. Potential maternal and infant outcomes from coronavirus 2019NCOV (SARS-CoV-2) infecting pregnant women: Lessons from SARS, MERS, and other human coronavirus infections. Viruses. 2020;12(2):1-16.

8. Yan W, Wang X, Kuang H, Chen Y, Baktash MB, Eskenazi B, et al. Physical activity and blood pressure during pregnancy: Mediation by anxiety symptoms. J Affect Disord [Internet]. 2020;264(November):376-82. Available from: https://doi.org/10.1016/j.jad.2019.1 1.056

9. Chasson M, Taubman - Ben-Ari O, Abu-Sharkia S. Jewish and Arab pregnant women's psychological distress during the COVID-19 pandemic: the contribution of personal resources. Ethn Heal. 2020;

10. Glover V. Maternal depression, anxiety and stress during pregnancy and child outcome; What needs to be done. Best Pract Res Clin Obstet Gynaecol [Internet]. 2014;28(1):25-35. Available from: http://dx.doi.org/10.1016/j.bpobgyn .2013.08.017

11. Martini J, Petzoldt J, Einsle F, Beesdo-Baum K, Höfler M, Wittchen HU. Risk factors and course patterns of anxiety and depressive disorders during pregnancy and after delivery: A prospective-longitudinal study. J Affect Disord. 2015;175:385-95.

12. Ding XX, Wu Y Le, Xu SJ, Zhu RP, Jia XM, Zhang SF, et al.
Maternal anxiety during pregnancy and adverse birth outcomes: A systematic review and metaanalysis of prospective cohort studies. J Affect Disord. 2014;159(81):103-10.

13. Coelho HF, Murray L, RoyalLawson M, Cooper PJ. Antenatal anxiety disorder as a predictor of postnatal depression: A longitudinal study. J Affect Disord [Internet]. 2011;129(1-3):348-53. Available from: http://dx.doi.org/10.1016/j.jad.2010 .08 .002

14. Lindgren K. Relationships among maternal-fetal attachment, prenatal depression, and health practices in pregnancy. Res Nurs Heal. 2001;24(3):203-17.

15. Shahhosseini Z, Pourasghar M, Khalilian A, Salehi F. A Review of the Effects of Anxiety During Pregnancy on Children's Health. Mater Socio Medica. 2015;27(3):200.

16. Brunton PJ. Effects of maternal exposure to social stress during pregnancy: Consequences for mother and offspring. Reproduction. 2013;146(5).

17. Roy D, Tripathy S, Kar SK, Sharma N, Verma SK, Kaushal V. Study of knowledge, attitude, anxiety \& perceived mental healthcare need in Indian population during COVID-19 pandemic. Asian J Psychiatr [Internet]. 2020;51(April):102083. Available from: https://doi.org/10.1016/j.ajp.2020.1 02083

18. Nasab MB, Bahmaei H, Askari S, Ghanbari S, Iravani M. The Relationship between Health Anxiety and Prenatal Distress with Choosing the Type of Childbirth in Pregnant Women during Covid-19 
Outbreaks in Iran. Res Sq. 2020;116.

19. Nwafor JI, Okedo-Alex IN, Ikeotuonye AC. Prevalence and predictors of depression, anxiety and stress symptoms among pregnant women during COVID19-related lockdown in Abakaliki, Nigeria. medRxiv. 2020;3-10.

20. Luo Y, Yin K. Management of pregnant women infected with COVID-19. Lancet Infect Dis [Internet]. 2020;20(5):513-4. Available from: http://dx.doi.org/10.1016/S14733099(20)30191-2

21. Fakari FR, Simbar M. Coronavirus Pandemic and Worries during Pregnancy. JournalsSbmuAcIr [Internet]. 2020;8(January):2-3. Available from: http://journals.sbmu.ac.ir/aaem

22. Taubman-Ben-Ari O, Chasson M, Abu Sharkia S, Weiss E. Distress and anxiety associated with COVID-19 among Jewish and Arab pregnant women in Israel. J Reprod Infant Psychol [Internet]. 2020;38(3):340-8. Available from: https://doi.org/10.1080/02646838.2 020.1786037

23. Yue C, Liu C, Wang J, Zhang M, $\mathrm{Wu} \mathrm{H}, \mathrm{Li} \mathrm{C}$, et al. Association between social support and anxiety among pregnant women in the third trimester during the coronavirus disease 2019 (COVID-19) epidemic in Qingdao, China: The mediating effect of risk perception. Int J Soc Psychiatry. 2020;(308).

24. Maharlouei N, Keshavarz P, Lankarani KB. Depression and Anxiety Among Pregnant Mothers in the Initial Stage of the Coronavirus Disease (COVID-19) Pandemic in Southwest of Iran. Res Sq [Internet]. 2020;1-15. Available from: https://www.researchsquare.com/art icle/rs-

71528/latest?utm_source=researche r_app\&utm_medium=referral\&utm _campaign=RESR_MRKT_Resear cher_inbound

25. Dagklis T, Tsakiridis I, Mamopoulos A, Athanasiadis A, Papazisis G. Anxiety During Pregnancy in the Era of the COVID-19 Pandemic. SSRN Electron J. 2020;

26. Wu Y, Zhang C, Liu H, Duan C, Li $\mathrm{C}$, Fan J, et al. Perinatal depressive and anxiety symptoms of pregnant women during the coronavirus disease 2019 outbreak in China. Am J Obstet Gynecol [Internet]. 2020;223(2):240.e1-240.e9.

Available from: https://doi.org/10.1016/j.ajog.2020. 05.009

27. Castro P, Castro P, Narciso C, Matos AP, Werner H, Araujo E, et al. Pregnant, uninfected, stressed, and confined in the COVID-19 period: What can we expect in the near future? Rev Assoc Med Bras. 2020;66(4):386-7.

28. Ahorsu DK, Imani V, Lin CY, Timpka T, Broström A, Updegraff JA, et al. Associations Between Fear of COVID-19, Mental Health, and Preventive Behaviours Across Pregnant Women and Husbands: An Actor-Partner Interdependence Modelling. Int J Ment Health Addict. 2020;

29. Corbett GA, Milne SJ, Mohan S, Reagu S, Farrell T, Lindow SW, et al. Anxiety and Depression Scores in Maternity Healthcare Workers during the Covid-19 Pandemic. Int J Gynecol Obstet. 2020;(June):167.

30. Davenport MH, Meyer S, Meah VL, Strynadka MC, Khurana R. Moms Are Not OK: COVID-19 
and Maternal Mental Health. Front Glob Women's Heal.

2020;1(June):1-6.

31. Ravaldi C, Ricca V, Wilson A, Homer C, Vannacci A. Previous psychopathology predicted severe COVID-19 concern, anxiety and PTSD symptoms in pregnant women during lockdown in Italy. medRxiv [Internet]. 2020;2020.08.26.20182436.

Available from: https://doi.org/10.1101/2020.08.26. 20182436

32. Moyer C, Compton S, Kaselitz E, Muzik M. Pregnancy-related anxiety during COVID-19: A nationwide survey of 2,740 pregnant women. 2020;1-16.

33. Biaggi A, Conroy S, Pawlby S, Pariante CM. Identifying the women at risk of antenatal anxiety and depression: A systematic review. J Affect Disord [Internet]. 2016;191:62-77. Available from: http://dx.doi.org/10.1016/j.jad.2015 .11 .014

34. Liu X, Chen M, Wang Y, Sun L, Zhang J, Shi Y, et al. Prenatal anxiety and obstetric decisions among pregnant women in Wuhan and Chongqing during the COVID19 outbreak: a cross-sectional study. BJOG An Int J Obstet Gynaecol. 2020;127(10):1229-40.

35. Patabendige M, Gamage MM, Weerasinghe M, Jayawardane A. Psychological impact of the COVID-19 pandemic among pregnant women in Sri Lanka. Int $\mathrm{J}$ Gynecol Obstet. 2020;151(1):1503.

36. Tang X, Lu Z, Hu D, Zhong X. Influencing factors for prenatal Stress, anxiety and depression in early pregnancy among women in Chongqing, China. J Affect Disord. 2019;253(May):292-302.
37. Kang YT, Yao Y, Dou J, Guo X, Li $\mathrm{SY}$, Zhao CN, et al. Prevalence and risk factors of maternal anxiety in late pregnancy in China. Int $\mathbf{J}$ Environ Res Public Health. 2016;13(5).

38. Zhang Y, Muyiduli X, Wang S, Jiang W, Wu J, Li M, et al. Prevalence and relevant factors of anxiety and depression among pregnant women in a cohort study from south-east China. J Reprod Infant Psychol [Internet]. 2018;36(5):519-29. Available from: https://doi.org/10.1080/02646838.2 018.1492098

39. Saccone G, Florio A, Aiello F, Venturella R, De Angelis MC, Locci M, et al. Psychological impact of coronavirus disease 2019 in pregnant women. Am J Obstet Gynecol. 2020;223(2):293-5.

40. Suda T, Miura Y, Katayama M, Senba H, Takahata M, Nakano S. Worries and concerns about COVID-19 lockdown aggravate stress reactions among pregnant women. 2020;1-13. Available from: https://doi.org/10.21203/rs.3.rs45832/v1 